EXPERIMENTAL STUDY

\title{
Gonadal malignant germ cell tumors express immunoreactive inhibin/activin subunits
}

Luigi Cobellis, Palmina Cataldi, Fernando M Reis, Giuseppe De Palo ${ }^{1}$, Francesco Raspagliesi ${ }^{1}$, Silvana Pilotti ${ }^{1}$, Felice Arcuri ${ }^{2}$ and Felice Petraglia

Chair of Obstetrics and Gynecology, University of Siena, Siena, Italy, ${ }^{1}$ Istituto Nazionale Tumori, Milan, Italy and ${ }^{2}$ Institute of Pathological Anatomy and Histology, University of Siena, Siena, Italy

(Correspondence should be addressed to Felice Petraglia, Chair of Obstetrics and Gynecology, University of Siena, Policlinico Le Scotte, Viale Bracci, 53100 Siena, Italy; Email: petraglia@unisi.it)

\begin{abstract}
Objective: Inhibin and activin are proteins produced by ovarian granulosa cells and testicular Sertoli cells and are members of the transforming growth factor- $\beta$ superfamily. Since increased circulating levels of immunoreactive inhibin were detected in women with malignant ovarian tumors, they were proposed as tumor markers for ovarian carcinoma. Immunohistochemical studies later confirmed the presence of inhibin and activin subunits in granulosa cell tumors and epithelial ovarian cancer, as well as in Sertoli and Leydig cell testicular cancer. However, there is discrepant information on the detection of inhibin and activin in malignant germ cell tumors (MGCT). The aim of the present study was to evaluate the immunohistochemical expression of the inhibin/activin $\alpha, \beta A$ and $\beta B$ subunits in ovarian and testicular MGCT specimens using polyclonal antisera.

Methods: The ovarian tissue samples were composed of 19 MGCT, including dysgerminoma $(n=18)$ and yolk sac tumor $(n=1)$. The testis specimens included classic seminomas $(n=20)$, embryonal carcinomas $(n=7)$, choriocarcinomas $(n=2)$, and yolk sac tumor $(n=1)$.

Results: Ovarian and testicular malignant germ cell tumors expressed positive staining for inhibin/ activin $\alpha, \beta$ A and $\beta B$ subunits, with some variations between and within individual tumors: while ovarian dysgerminomas were diffusely positive for $\alpha, \beta A$ and $\beta B$, testicular tumors expressed $\alpha$ and $\beta B$ subunits, whereas $\beta$ A staining was weak.

Conclusions: The present results show positive staining for inhibin/activin subunits in ovarian and testicular MGCT, suggesting a possible role in tumorigenesis with the resultant clinical implication.
\end{abstract}

European Journal of Endocrinology 145 779-784

\section{Introduction}

Inhibin and activin are members of the transforming growth factor- $\beta$ (TGF- $\beta$ ) superfamily. Inhibin is composed of a common $\alpha$ subunit and one of two $\beta$-subunits $(\beta A$ and $\beta B)$, resulting in inhibin $A(\alpha \beta A)$ and inhibin $B$ $(\alpha \beta B)$. Activin is a dimer composed of two inhibin $\beta$ subunits, and activin $A(\beta A \beta A)$, activin $B(\beta B \beta B)$ and activin $A B(\beta A \beta B)$ are recognized (1). First isolated from the gonads, they were recognized as hormones and named inhibins and activins because of their opposing effects on pituitary follicle-stimulating hormone (FSH) secretion. Further investigations elucidated their sequence homology with TGF- $\beta$ and their effect on cell differentiation and proliferation in various organs, suggesting a role as growth factors (1-3).

Serum inhibin was proposed as a tumor marker since high serum immunoreactive inhibin levels were detected in women with malignant ovarian tumors (4). This hypothesis has been intensively investigated and high circulating inhibin $\mathrm{A}$ and activin $\mathrm{A}$ levels have been shown in women with epithelial ovarian tumors $(5,6)$ while inhibin B is increased in patients with granulosa cell tumors $(7,8)$. Immunohistochemical studies have confirmed the presence of inhibin/activin subunits in granulosa cell tumors and epithelial ovarian cancer $(9-15)$. In the meantime, the evidence that ovarian tumors developed in inhibin $\alpha$ knock-out mice strongly supported the possible role of these proteins in ovarian tumorigenesis (16). On the other hand, no evidence of increased inhibin levels in men with testicular tumors has been shown, but immunohistochemical localization of inhibin subunits in Sertoli cell tumors and Leydig cell tumors was shown $(17,18)$.

Ovarian and testicular malignant germ cell tumors (MGCT) derive from primitive germ cells of the embryonic gonad and represent $5-6 \%$ of ovarian neoplasms (19) and 95\% of testicular neoplasms (20). Dysgerminoma is the most common ovarian MGCT form, whereas seminoma is the commonest histological type 
in the testis. Conflicting data are available on the immunohistochemical detection of inhibin $\alpha$ subunit in ovarian MGCT $(9,13,17,18)$, with no information on inhibin/activin $\beta A$ and $\beta B$ subunits, and little information on testicular MGCT (14). The aim of the present study was to evaluate the immunohistochemical expression of inhibin/activin $\alpha, \beta A$ and $\beta B$ subunits in ovarian and testicular MGCT.

\section{Materials and methods}

\section{Tissues samples}

Specimens from ovarian and testicular MGCT $(n=49)$ were evaluated: they were composed of ovarian MGCT $(n=19)$ and testicular MGCT $(n=30)$.

Ovarian MGCT included dysgerminomas $(n=18)$ (patient age range 9-24 years, median 17.2) and yolk sac tumor $(n=1)$ (patient aged 40$)$ according to the World Health Organisation (WHO) classification (21) and were retrieved from the files of the Istituto Tumori of Milan. The tissues were fixed in Bouin's fluid and embedded in paraffin.

Testicular MGCT included 20 classic seminomas $(n=$ 20) (patient age range 18-65 years, median 31.6), embryonal carcinomas $(n=7)$ (patient age range 18 42 , median 27.7), choriocarcinomas $(n=2)$ (patients aged 25 and 35$)$ and yolk sac tumor $(n=1)$ (patient aged 41) according to the WHO classification (22) and were selected from the files of the Department of Pathology of the University of Udine. The tissues were fixed in $10 \%$ buffered formalin and embedded in paraffin.

The expression of inhibin/activin $\alpha, \beta \mathrm{A}$ and $\beta \mathrm{B}$ subunits was studied by using an immunoperoxidase technique. All hematoxylin and eosin-stained slides were reviewed and representative sections of each case were selected for immunohistochemical staining. One paraffin block from dysgerminoma included residual normal ovary; in 18 cases of testicular tumors the selected sections showed residual atropic/subatropic testis.

\section{Immunohistochemistry}

Immunohistochemical analysis was performed on $5 \mu \mathrm{m}$ sections using the streptavidin-biotin-peroxidase technique. The sections were routinely deparaffinized, rehydrated and antigen retrieval was carried out by microwaving the slides at $800 \mathrm{~W}$ for $5 \mathrm{~min}$ and $300 \mathrm{~W}$ for $3 \mathrm{~min}$ in $0.01 \mathrm{~mol} / \mathrm{l}$ citrate buffer, $\mathrm{pH} \mathrm{7.3.} \mathrm{After}$ endogenous peroxidase blocking, the sections were incubated overnight at $4{ }^{\circ} \mathrm{C}$ with the following specific antibodies: rabbit anti $\alpha$ (1-26)-Gly-Tyr (diluted $1: 100)$; mouse anti- $\beta A(81-113)-\mathrm{NH}_{2}$ and mouse anti- $\beta \mathrm{B}(81-112)-\mathrm{NH}_{2}$ (diluted 1:10). These were affinity purified polyclonal antisera raised against synthetic peptide fragments (Salk Institute, La Jolla, CA, USA). A monoclonal antibody raised against the $\alpha$-inhibin subunit, clone R1 (diluted 1:100) was also used (Serotec,
Oxford, Oxon, UK) for comparison with previous studies (23).

The sections were then incubated with biotinylated link antibodies followed by peroxidase-conjugated streptavidin (LSABTM, Dako, Glostrup, Denmark) at room temperature for $30 \mathrm{~min}$ each. After peroxidase developing with 3,3'-diaminobenzidine/hydrogen peroxide, the slides were counterstained with hematoxylin, dehydrated and mounted.

Negative and positive controls were included in each staining series: first trimester placental tissue was used as a positive control and the same biopsy incubated with normal rabbit immunoglobulin or mouse ascites fluid instead of primary antibodies was used as a negative control.

The immunostaining was evaluated by estimating semiquantitatively the distribution and the intensity of positive cells. A positive reaction was characterized by the presence of granular brown staining. The staining was scored as diffuse ( $\geq 75 \%$ of tumor cells positive) or focal (partial) ( $<75 \%$ of tumor cells positive). The intensity of staining was graded semiquantitatively as follows: negative $(-)$; weak $(+)$; moderate $(++)$; strong $(+++)$.

\section{Results}

Ovarian and testicular MGCT expressed positive immunoreactivity for inhibin/activin $\alpha, \beta A$ and $\beta B$ subunits with some variations between and within individual tumors (Table 1). The antibodies detected cytoplasmic proteins in neoplastic cells, and in some sections a nuclear stain was observed. Since previous studies had shown no staining of inhibin $\alpha$ subunit, the same monoclonal antibody (23) was tested on our specimens and no positive signal was observed in any ovarian and testicular tumoral form; positive controls stained as expected.

In all cases with dysgerminomas $(n=18)$ a diffuse positive expression of $\alpha, \beta A$ and $\beta B$ subunits with

Table 1 Evaluation of the intensity of staining for inhibin/activin subunits $(\alpha, \beta A, \beta B)$, according to a subjective semiquantitative analysis.

\begin{tabular}{llll}
\hline Malignant germ cells tumor & Alpha & Beta A & Beta B \\
\hline Ovary & & & \\
Dysgerminoma $(n=18)$ & $+/++$ & $+/++^{\mathrm{a}}$ & $+/++$ \\
Yolk sac tumor $(n=1)$ & +++ & +++ & +++ \\
Testis & & & \\
Seminoma $(n=20)$ & $+/++$ & $+^{\mathrm{b}}$ & ++ \\
Embryonal carcinoma $(n=7)$ & ++ & $+^{\mathrm{c}}$ & ++ \\
Choriocarcinoma $(n=2)$ & $++/++$ & $+^{\mathrm{d}}$ & ++ \\
Yolk sac tumor $(n=1)$ & $++/+++$ & ++ & ++ \\
\hline
\end{tabular}

+, weak staining; ++, moderate staining; +++, strong staining.

All cases demonstrated diffuse immunostaining unless otherwise specified.

${ }^{a}$, focal staining in 5 cases; ${ }^{b}$, focal staining in 9 cases, diffuse in $11{ }^{c}$, focal staining in 4 cases, diffuse in 3 ; $^{d}$, focal staining in 2 cases. 
weak or moderate staining was found; in 5 cases the positivity for $\beta$ A subunits was focal. A finely distributed labeling of some nuclei was observed with the antibody to $\beta B$ subunit. In the ovarian yolk sac tumor a diffuse and strong cytoplasmic positive signal for $\alpha, \beta A$ and $\beta B$ subunits was shown, with a dot-like pattern for $\alpha$ subunit as well.

Testicular MGCT diffusely expressed $\alpha$ subunit in the cytoplasm. Weak or moderate intensity of $\alpha$ inhibin subunit was shown in seminomatous tumors, while a strong intensity resulted in non seminomatous tumors. A strong positive staining for the $\alpha$ subunit was also detected in syncytiotrophoblast cells present in 4 seminomas. A focal and weak cytoplasmic staining was observed for $\beta A$ subunit; only the yolk sac tumors showed a moderate staining. All testicular tumors showed a diffuse and moderate cytoplasmic positivity for $\beta \mathrm{B}$ subunit. Positive immunoreactivity for $\alpha$ and $\beta B$ inhibin/activin subunits in some nuclei of ovarian or testicular MGCT cells was also localized (Fig. 1).

\section{Discussion}

The present immunohistochemical results demonstrate for the first time positive staining for inhibin/activin $\alpha$, $\beta A$ and $\beta B$ subunits in ovarian and testicular MGCT, suggesting the possible expression of the different dimeric forms of inhibin/activin in this type of tumor.

Previously, the presence of immunoreactive inhibin $\alpha$ subunit in ovarian neoplasms was identified as a sensitive immunohistochemical marker of granulosa cell tumors (12), sex cord stromal tumor $(9,13)$ and epithelial tumors $(10,11,14)$. Sex cord stromal and epithelial ovarian tumors also showed $\beta A$ and $\beta B$ inhibin subunits immunolocalization $(15,24)$.

Among the testicular tumors, $\alpha$ inhibin subunit was expressed in $91 \%$ of the Sertoli cell tumors and in $100 \%$ of the Sertoli cell adenomas and Leydig cell tumors $(17,18)$.

Previous studies investigating the expression of $\alpha$ inhibin subunit using a monoclonal antibody showed conflicting data in ovarian forms of MGCT. Pelkey et al. (14) pointed out that the immunostaining of inhibin $\alpha$ in 7 cases of ovarian MGCT was negative, while in the testes $\alpha$ inhibin staining was positive in only one out of 13 seminoma cases in which the syncytiotrophoblast was present. The lack of any $\alpha$ inhibin staining was also shown in another six (25), twenty-four (26) and six (27) ovarian MGCT, except for a positive focus near syncytiotrophoblastic cells. On the other hand, Hussong et al. (28) reported positive $\alpha$ inhibin staining in $40 \%$ of ovarian MGCT using the same monoclonal antisera.

Our present results which showed diffuse $\alpha$ subunit staining in MGCT using the polyclonal antiserum but not when the R1 monoclonal antibody was tested on the same specimens, suggest that the lack of any $\alpha$ staining in the previous studies may depend upon the characteristics of the two antibodies. The present polyclonal $\alpha$ inhibin antiserum does not cross react with TGF- $\beta$, and has only $1 \%$ cross reactivity with $\beta A$ and $\beta B$ subunits (29); the question that remains open is the possible detection of free $\alpha$ subunit or pro- $\alpha-C$ - precursor. Therefore, part of our positive staining may be due to the detection of the dimeric forms of inhibins and/or to the precursor/free $\alpha$ subunit.

Several studies have investigated inhibin-related proteins in human fetal gonads. Immunohistochemical staining with a polyclonal antibody detected $\alpha$ subunit in interstitial and intratubular cells in midgestation testis, while $\beta A$ and $\beta B$ subunits occurred in Leydig cells. The primordial follicles, the most immature ovarian cell population recognizable, were negative for $\alpha$ and $\beta B$ subunits, and showed very weak staining for $\beta \mathrm{A}$ (30). Using Northern blot analysis, RT-PCR and in situ hybridization, fetal ovary during the second trimester of gestation failed to express inhibin subunits, in agreement with the hormonal inactivity of the ovary during intrauterine life $(31,32)$. On the other hand, positive results were seen in the testis with different staining and gene expression.

During reproductive age human primordial follicles show positive staining for $\beta A$ and $\beta B$ subunits, and are negative for $\alpha$ subunit. In the growing follicles all inhibin-related protein subunits are stained and the expression of mRNA shows an increasing intensity $(33,34)$.

Evidence that activin, together with follistatin and FSH, act and regulate germ cell maturation has recently been provided (35). Rat testis fragments in culture treated with activin show a high proportion of Sertoli cells derived from the germ cell compartment, an effect which is not demonstrable by adding follistatin and FSH in the culture medium. The differentiation of gonocytes in spermatogonia mediated, by activin, that represent the first Sertoli cell product, give reason to a pivotal role of inhibin-related proteins in germ cell differentiation (36). Moreover, activin receptors are expressed by testicular germ cells $(37,38)$, and are able to bind activin and inhibin (39). Testicular germ cell tumors express activin type I and type II receptors, and the presence of inhibin/activin $\beta A$ and $\beta B$ mRNAs in these tumors but not in normal germ cells suggests that testicular germ cell tumor development may, in part, be regulated and modulated by the inhibin/activin system (40).

Recently, serum inhibin B levels have been measured in men with various gonadal dysfunction; the group with germ cell failure, with elevated FSH levels and normal luteinizing hormone and testosterone levels, showed lower amounts of inhibin B compared with the control group (41). These data confirm that inhibin $B$ production in men is regulated by Sertoli cell function, plays a fundamental role in FSH secretion, and is positively correlated with spermatogenesis.

The immunohistochemical localization provides indirect evidence of these proteins; no other data are 


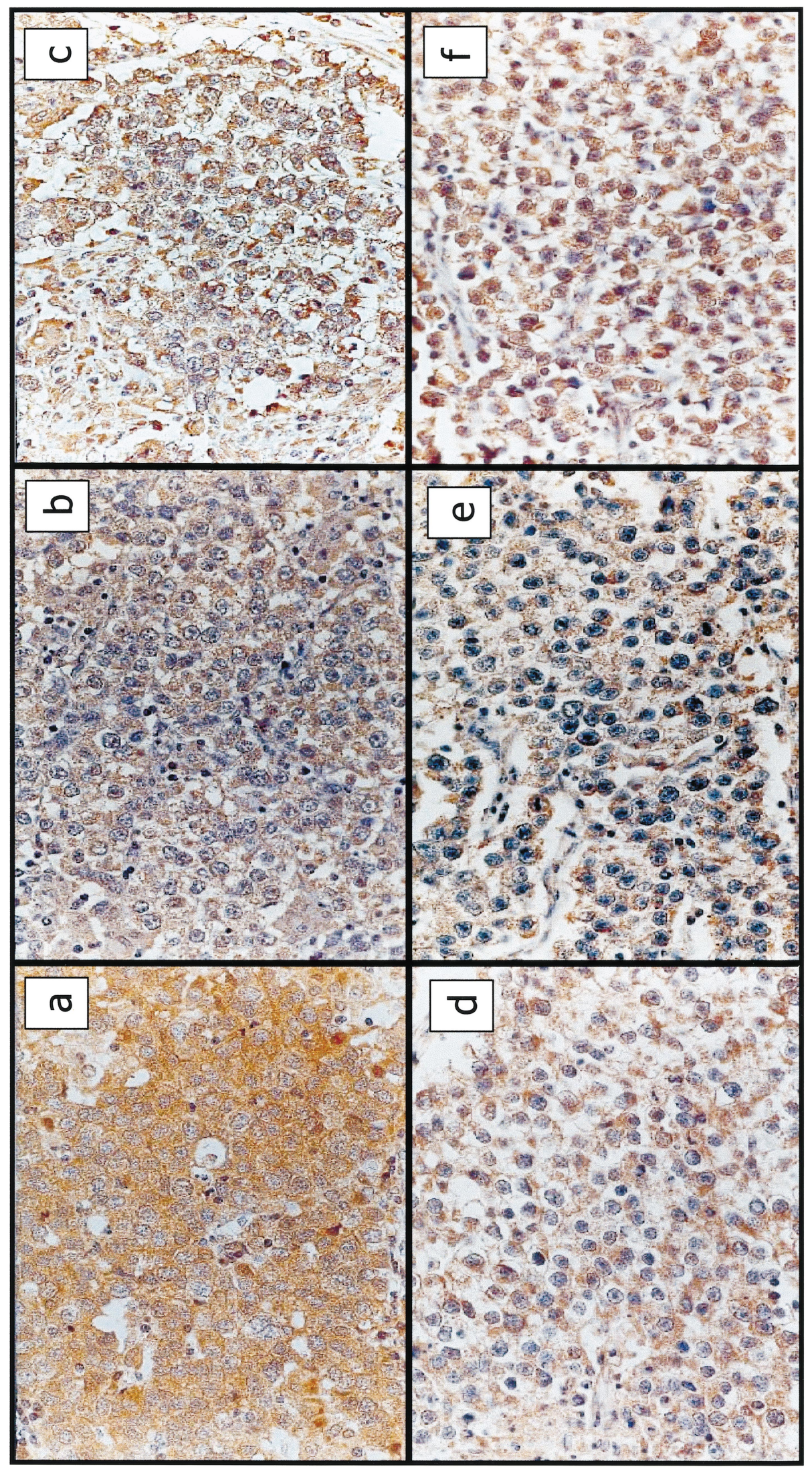

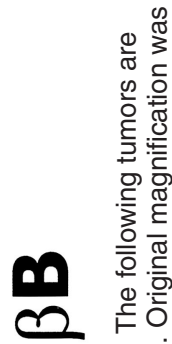

产.

등 홍

흔흔

वृ

웡

ฮิ

है을

응 흘

닌 즈음

잉 웡

不 흥

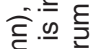

है?

O응

-1 迹

$\infty$

节 它

क응

政

论

등ㅎㅇ

을 을

흐를 을

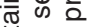

फ़ $\frac{0}{5}$

今 은 인

它

흘을

है क

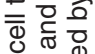

ह $\mathrm{O} \cdot \frac{\mathrm{T}}{\bar{T}}$

3

ฮ융

흔 뜌

के

응 क्ष

등

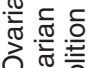

- 0 원

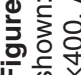


available for germ cell ovarian neoplasms due to the rarity of these tumors.

MGCT arise from a germinal cell which is totipotent. Inhibin/activin are present during embryonic development and have a role in cellular differentiation; later they may be expressed again when a malignancy occurs. The expression of $\beta A$ activin mRNA is an event common to various tumor organs (uterus, liver, adrenal, pancreatic, prostate, breast) $(42-47)$ thus suggesting a biological role of activins in tumorigenesis, independent of the tissue of origin.

The positive staining of both $\beta \mathrm{A}$ and $\beta \mathrm{B}$ activin subunits in ovarian and testicular MGCT suggests the possible expression of activin dimers and/or free subunits in these tumors. This is indirect evidence that inhibinrelated proteins are present in this type of tumor; a possible role in tumorigenesis is unknown and the putative clinical implication remains to be evaluated.

\section{Acknowledgements}

We kindly thank Dr Wylie Vale and Mrs Joan Vaughan, Salk Institute (La Jolla, CA, USA), for providing the antisera against inhibin/activin $\alpha, \beta A$ and $\beta B$ subunits, and Dr Nigell Groome (Oxford, UK) for providing the monoclonal antiserum (R1) against inhibin $\alpha$ subunit.

\section{References}

1 Vale W, Rivier C, Hsueh A, Campen C, Meunier H, Bicsak T et al. Chemical and biochemical characterization of the inhibin family protein hormones. Recent Progress in Hormone Research $19884 \mathbf{4}$ $1-34$.

2 Healy DL, Mamers P, Bangah M \& Burger HG. Clinical and pathophysiologic aspects of inhibin. Human Reproduction $1993 \mathbf{8}$ 138-140.

3 Burger HG. Clinical utility of inhibin measurements. Journal of Clinical Endocrinology and Metabolism 199376 1391-1396.

4 Healy DL, Burger HG, Mamers P, Jobling T, Bangah M, Quinn M et al. Elevated serum inhibin concentrations in postmenopausal women with ovarian tumours. New England Journal of Medicine 1993329 1539-1542.

5 Cooke I, O'Brien MO, Charnock FM, Groome N \& Gamesan TS. Inhibin as a marker for ovarian cancer. British Journal of Cancer 199571 1046-1050.

6 Lambert-Messerlian G, Steinhoff M, Zheng W, Canick J, Seifer D \& Schneyer A. Characterization of immunoreactive form of inhibin in serum of pre and postmenopausal women with epithelial ovarian cancer. Gynecologic Oncology 199765 512-516.

7 Petraglia F, Luisi S, Pautier P, Sabourin JC, Rey R, Lhomme C et al. Inhibin $\mathrm{B}$ is the major form of inhibin/activin family secreted by granulosa cell tumors. Journal of Clinical Endocrinology and Metabolism 199883 1029-1032.

8 Burger HG, Baillie A, Drummond AE, Healy DL, Jobling T, Mamers $\mathrm{P}$ et al. Inhibin and ovarian cancer. Journal of Reproductive Immunology $19983977-87$.

9 Zheng W, Sung CJ, Hanna I, Lambert-Messerlian G, Steinhoff M \& Lauchlan SC. $\alpha$ and $\beta$ subunits of inhibin/activin as sex cordstromal differentiation markers. International Journal of Gynecological Pathology 199716 263-271.

10 Arora DS, Cooke IE, Ganesan TS, Ramsdale J, Manek S, Charnock FML et al. Immunohistochemical expression of inhibin/activin subunits in epithelial and granulosa cell tumours of the ovary. Journal of Pathology $1997 \mathbf{1 8 1} 413-418$.

11 Gurusinghe CJ, Healy DL, Jobling T, Mamers P \& Burger HG. Inhibin and activin are demonstrable by immunohistochemistry in ovarian tumor tissue. Gynecologic Oncology 199557 27-32.

12 Flemming P, Wellmann A, Maschek H, Lang H \& Georgii A. Monoclonal antibodies against inhibin represent key markers of adult granulosa cell tumors of the ovary even in their metastases. American Journal of Surgical Pathology 199519 927-933.

13 Rishi M, Howard LN, Bratthauer GL \& Tavassoli FA. Use of monoclonal antibody against human inhibin as a marker for sex cordstromal tumors of the ovary. American Journal of Surgical Pathology 199721 583-589.

14 Pelkey TJ, Frierson HF Jr, Mills SE \& Stoler MH. The diagnostic utility of inhibin staining in ovarian neoplasms. International Journal of Gynecological Pathology 1998 17 97-105.

15 Yamashita K, Yamoto M, Shinone T, Minami S \& Nakano R. Immunohistochemical localization of inhibin and activin subunits in human epithelial ovarian tumors. American Journal of Obstetrics and Gynecology $1999 \mathbf{1 8 0} 316-322$.

16 Matzuk MM, Finegold MJ, Su JGJ, Hsueh A \& Bradley A. Alphainhibin is a tumor-suppressor gene with gonadal specificity in mice. Nature $1992360313-319$.

17 McCluggage WG, Shanks JH, Whiteside C, Maxwell P, Banerjee SS \& Biggart JD. Immunohistochemical study of testicular sex cordstromal tumors, including staining with anti-inhibin antibody. American Journal of Surgical Pathology 199822 615-619.

18 Iczkowski KA, Bostwick DG, Roche PC \& Cheville JC. Inhibin A is a sensitive and specific marker for testicular sex cord-stromal tumors. Modern Pathology 199811 774-779.

19 Gershenson DM. Update on malignant ovarian germ cell tumors. Cancer 199371 1581-1590.

20 Forman D \& Møller H. Testicular cancer. Cancer Surveys 199420 $323-341$.

21 Scully RE, Bonfiglio TA, Kurman RJ, Silverberg SG, Wilkinson EJ. Histological Typing of Female Genital Tract Tumors. 2nd edition. World Health Organization. Heidelberg: Springer-Verlag Berlin, 1994.

22 Mostofi FK, Sesterhenn IA. Histological Typing of Testis Tumors, 2nd edition. World Health Organization. Heidelberg: Springer-Verlag Berlin, 1998.

23 Groome N, Hancock J, Betteridge A, Lawrence M \& Craven R. Monoclonal and polyclonal antibodies reactive with the 1-32 amino terminal sequence of the alpha subunit of human $32 \mathrm{~K}$ inhibin. Hybridoma 19909 31-42.

24 Yamashita K, Yamoto M, Shinone T, Minami S, Imai M, Nishimori $\mathrm{K}$ et al. Production of inhibin A and inhibin B in human ovarian sex cord stromal tumors. American Journal of Obstetrics and Gynecology 1997177 1450-1457.

25 Costa MJ, Ames PF, Walls J \& Roth LM. Inhibin immunohistochemistry applied to ovarian neoplasms: a novel, effective, diagnostic tool. Human Pathology 199728 1247-1254.

26 Kommoss F, Oliva E, Bhan AK, Young RH \& Scully RE. Inhibin expression in ovarian tumors and tumor-like lesions: an immunohistochemical study. Modern Pathology 199811 656-664.

27 Riopel MA, Perlman EJ, Seidman JD, Kurman RJ \& Sherman ME. Inhibin and epithelial membrane antigen immunohistochemistry assist in the diagnosis of sex cord-stromal tumors and provide clues to the histogenesis of hypercalcemic small cell carcinomas. International Journal of Gynecological Pathology $19981746-53$.

28 Hussong J, Woodruff T \& Keh PC. Immunohistochemical study of primary ovarian tumors with inhibin antibody. Modern Pathology 19971 102A.

29 Vaughan JM, Rivier J, Corrigan AZ, McClintock R, Campen CA, Jolley D et al. Detection and purification of inhibin using antisera generated against synthetic peptide fragments. Methods in Enzymology 1989168 588-617.

30 Rabinovici J, Goldsmith PC, Roberts VJ, Vaughan J, Vale W \& Jaffe RB. Localization and secretion of inhibin/activin subunits in the 
human and subhuman primate fetal gonads. Journal of Clinical Endocrinology and Metabolism 199173 1141-1149.

31 Voutilanen R, Erämaa M \& Ritvos O. Hormonally regulated inhibin gene expression in human fetal and adult adrenals. Journal of Clinical Endocrinology and Metabolism 199173 1026-1030.

32 Erämaa M, Heikinheimo K \& Voutilanen R. Development and cyclic adenosine $3^{\prime}, 5^{\prime}$ monophosphate-dependent regulation of inhibin subunit messenger ribonucleic acids in human fetal testes. Journal of Clinical Endocrinology and Metabolism $1992 \quad 75$ $806-811$.

33 Yamoto M, Minami S, Nakano R \& Kobayashi M. Immunohistochemical localization of inhibin/activin subunits in human ovarian follicles during the menstrual cycle. Journal of Clinical Endocrinology and Metabolism 1991 74 989-993.

34 Roberts VJ, Barth S, El-Roeiy A \& Yen SSC. Expression of inhibin/ activin subunits and follistatin messenger ribonucleic acids and proteins in ovarian follicles and the corpus luteum during the human menstrual cycle. Journal of Clinical Endocrinology and Metabolism 199377 1402-1410.

35 Meehan T, Schlatt S, O’Bryan MK, de Krester DM \& Loveland KL. Regulation of germ cell and Sertoli cell development by activin follistatin and FSH. Developmental Biology 2000220 225-237.

36 Meinhardt A, McFarlane JR, Seitz J \& de Krester DM. Activin maintains the condensal type of mitochondria in germ cells. Molecular and Cellular Endocrinology 2000168 111-117.

37 de Winter JP, Themmen APN, Hoogerbrugge JW, Klaij IA, Grootegoed JA \& de Jong FH. Activin receptor mRNA expression in rat testicular cell types. Molecular and Cellular Endocrinology 1992 $83 \mathrm{R} 1-\mathrm{R} 8$

38 Cameron VA, Nishimura E, Mathews LS, Lewis KA, Sawchenko PE \& Vale WW. Hybridization histochemical localization of activin receptor subtypes in rat brain, pituitary, ovary, and testis. Endocrinology 1994134 799-808.

39 Woodruff TK, Borree J, Attie KM, Cox ET, Rice GC \& Mather JP Stage-specific binding of inhibin and activin to subpopulations of rat germ cells. Endocrinology 1992130 871-878.
40 van Schaik RH, Wierikx CDJ, Looijenga LHJ, Oosterhuis JW \& de Jong FH. Human testicular germ cell tumors express inhibin subunits, activin receptors and follistatin mRNAs. British Journal of Cancer 199776 1191-1198.

41 Kolb BA, Stanczyk FZ \& Sokol RZ. Serum inhibin B levels in males with gonadal dysfuntion. Fertility and Sterility $2000 \mathbf{7 4} 234-238$.

42 Petraglia F, Florio P, Luisi S, Gallo R, Gadducci A, Viganò P et al. Expression and secretion of inhibin and activin in normal and neoplastic uterine tissue. High levels of serum activin A in women with endometrial and cervical carcinoma. Journal of Clinical Endocrinology and Metabolism 199883 1194-1200.

43 McCluggage WG, Maxwell P, Patterson A \& Sloan JM. Immunohistochemical staining of hepatocellular carcinoma with monoclonal antibody against inhibin. Histopathology $199730518-522$.

44 Munro LM, Kennedy A \& McNicol AM. The expression of inhibin/ activin subunits in the human adrenal cortex and its tumours. Journal of Endocrinology 1999161 341-347.

45 Kleff J, Ishiwata T, Friess H, Buchler MW \& Korc M. Concomitant over-expression of inhibin/activin beta subunits and their receptors in human pancreatic cancer. International Journal of Cancer $199811860-868$

46 van Schaik RH, Wierikx CDJ, Timmerman MA, Oomen MH, van Weerden WM, van Steenbrugge GJ et al. Variations in activin receptor, inhibin/activin subunit and follistatin mRNAs in human prostate tissues. British Journal of Cancer 200082 $112-117$.

47 Di Loreto C, Reis FM, Cataldi P, Zuiani C, Luisi S, Beltrami CA et al. Human mammary gland and breast carcinoma contain immunoreactive inhibin/activin subunits: evidence for a secretion into cystic fluid. European Journal of Endocrinology $1999 \mathbf{1 4 1}$ $190-194$

Received 27 February 2001

Accepted 31 August 2001 